Paideusis

\title{
Longing to Connect: Spirituality in Public Schools
}

\section{Daniel Vokey}

Volume 13, Number 2, 2000

URI: https://id.erudit.org/iderudit/1073014ar

DOI: https://doi.org/10.7202/1073014ar

See table of contents

Publisher(s)

Canadian Philosophy of Education Society

\section{ISSN}

0838-4517 (print)

1916-0348 (digital)

Explore this journal

Cite this article

Vokey, D. (2000). Longing to Connect: Spirituality in Public Schools. Paideusis, 13(2), 23-41. https://doi.org/10.7202/1073014ar viewed online.

https://apropos.erudit.org/en/users/policy-on-use/ 


\title{
Longing to Connect: Spirituality in Public Schools
}

\section{Daniel Vokey, University of Prince Edward Island}

\begin{abstract}
We all know that what will transform education is not another theory, another book, or another formula, but educators who are willing to seek a transformed way of being in the world.
\end{abstract}

- Parker Palmer

A growing number of authors are proposing that spirituality be incorporated within the curricula of public schools. ${ }^{1}$ In making such proposals, many of these authors are responding to what they perceive as crises in public education caused at least in part by the exclusion of genuine spirituality from elementary and secondary classrooms. Many look to spirituality for a "safe" alternative to religion-safe in the sense of being independent from particular religious traditions and therefore acceptable for inclusion in the public schools of pluralistic liberal democracies. These authors take spirituality to be universal where religion is particular, and so believe that introducing or reintroducing spirituality into public schools would not compromise liberal principles protecting individual autonomy and cultural diversity.

In this paper, I discuss in very general terms the prospects for success of proposals to incorporate spirituality within public school curricula. Part one presents three themes from the literature on spirituality in education to summarize what its advocates believe their initiatives would offer students and teachers. Part two describes the obstacles I see to including programs of spiritual development within state-run schools. Part three outlines three projects that, by addressing those obstacles, would help create the conditions under which spirituality might be incorporated into public education in a proper and meaningful way.

\section{What will spirituality offer students and teachers?}

Theme 1: Renewed Life, Energy, and Enthusiasm

For many advocates of spirituality, the crisis of public schooling is that classes are deadly dull. They are deadly dull for students, and deadly dull for teachers. I use the modifier deadly advisedly, because dead is how students typically are described when they have lost their sense of wonder and with it their enthusiasm for learning. Fox (1998, p. 50) states that "The modern age and its forms of education and mass media can readily kill awe. . . Education that ignores awe kills 
the soul." Similarly, Parker Palmer (1999, pp. 17-19) describes public schooling as "death-dealing" precisely because "we have driven the sacred out of it."

One way in which spirituality in public schooling would seek to restore life, energy, and enthusiasm to classrooms is to spark student curiosity. As Albert Einstein suggests, wonder and awe might be fostered by inviting students to step to the edge of human knowledge and peer into the mystery beyond:

The most beautiful and profound emotion we can experience is the sensation of the mystical. It is the source of all true science and art. We to whom this emotion is a stranger, who can no longer wonder and stand rapt in awe, are as good as dead. To know that what is impenetrable to us really exists, manifesting itself as the highest wisdom and the most radiant beauty which our dull faculties can comprehend only in their most primitive forms-this knowledge, this feeling is at the centre of true religiousness. (Einstein, cited in COBWS, 1982, p. 150)

For those who are not sure how or even whether we should induce mystical experiences in the classroom, less esoteric ways have also been proposed to inspire wonder and awe in students and to restore their enthusiasm for learning. Some of these involve teachers simply encouraging students to slow down and "smell the roses"- or the lilacs, as the case may be (Scheindlin, 1999). Some authors remind us that there is no need to instil a sense of mystery in younger children, as most will bring their natural curiosity and thirst for learning with them to school. The following poem illustrates this well:

I am a being of life--striving toward recognition and enlightenment

I have been shaped by the moonlight and bathed in stardust

My life began in the womb of a great woman the bearer of all things

wonderful and sweet

Raised on dewdrops and mint, I have learned to fly on my own two beautiful wings.

A deep cavemous well is my mind with little drops of knowledge

The sound of my passion for life reverberates through my entire soul.

falling in one by one

I am myself and I am all.

(Charlotte Langley, cited in Barnes, 2000)

Particularly in the early grades, the task facing teachers is not so much to create ex nihilo a sense of wonder and awe in students as to keep schooling from killing their natural energy and curiosity. ${ }^{2}$

Some of the authors concerned about low energy in classrooms link it to a lack of higher purpose for school learning. They protest that contemporary curricula stifle wonder, awe, and curiosity by requiring students to absorb fragments of unconnected information, which students (and even teachers) experience as meaningless (cf. Iannone \& Iannone, 1999, p. 738). Students are not encouraged to 
ask the "big questions" about what life and learning are all about, and teachers (not without reason)often avoid such questions, and the controversies that go with them, like the proverbial plague (Kessler, 1998, p. 51). On this account, then, students and teachers often find schooling deadly dull because they perceive no intrinsic meaning in what they are required to do. To quote Palmer again:

When we fail to honor the deepest questions of our lives, education remains mired in technical triviality, cultural banality, and worse: it continues to be dragged down by a great sadness. I mean the sadness one feels in too many schools where teachers and students alike spend their days on things unworthy of the human heart-a grief that may mask itself as boredom, sullenness, or anger, but that is, at bottom, a cry for meaning. ${ }^{3}$

Postman (1995, p. 4) shares a similar observation about the loss in our schools of a shared narrative about the intrinsic value or higher purposes of education: "Without a narrative, life has no meaning. Without meaning, learning has no purpose. Without a purpose, schools are houses of detention, not attention."

Some proponents of spirituality in schools argue that the boredom and meaninglessness students experience compels them to seek excitement in danger or an outlet for their frustration in aggressive behaviour. Kessler (1998, p. 49), for example, claims that "Drugs, sex, gang violence, and even suicide may be both a search for connection and meaning and an escape from the pain of not having a genuine source of spiritual fulfilment." On the flip side, Kazanjian (1998) reports that curricula which help students make connections between schooling and "real life" are experienced as meaningful, inspiring, and even joyful. In particular, lessons or discussions that encourage students to grapple with the "big questions" at the centre of their lives are recommended as a way to bring "soul" back to the classroom (Kessler, 1999). For those of us who might worry that providing a higher purpose to learning will involve imposing some master narrative on students, Palmer (1998, p. 8) reassures us that "spiritual mentoring is not about dictating answers to the deep questions of life. It is about helping young people find questions that are worth asking because they are worth living, questions worth wrapping one's life around." For many advocates, then, incorporating spirituality within the curricula of public schools means creating opportunities and offering support for students to explore the meaning of life and corresponding higher purposes of learning.

Theme 2: Acceptance of Self, Compassion for Others

On some accounts, incorporating spirituality in public schools will help students not only find meaning and excitement in the regular curriculum but also 
learn to accept themselves and feel compassion for others. Here, bringing spirituality into the classroom means inviting students to encounter their "inner selves" and the interior lives of others in a more open, profound, and caring way than is usually possible in schools:

When soul enters the classroom, masks drop away. Students dare to share the joy and the talents they feared would provoke jealousy. They risk exposing the pain or shame that might be judged as weakness. Seeing deeply into the perspective of others, accepting what they thought unworthy in themselves, students discover compassion and begin to learn about forgiveness. (Kessler, 1998, p. 50)

Similarly, some authors propose that students can discover through spirituality a core of common humanity within their differences (Foxworth, 1998), and that such experiences lead students to active concern for the well-being of others outside as well as inside schools. For example, lannone \& Iannone (1999) propose that "once we recognize the spirituality in us, we then will recognize in others, especially the enslaved and oppressed, that need to be set free and enter into the world of justice." Other authors go further, maintaining that we can learn to extend compassion to all beings through an appreciation of our interdependence. "All education worthy of the name is education in compassion" says Fox (1998, p. 49), and "We teach compassion by teaching interdependence." For these authors, incorporating spirituality in public schools means bringing students to an experience of the sacredness of all life and to an apprehension of the intrinsic worthiness of all beings.

The call for schools to cultivate in students acceptance of self and compassion for others closely parallels the demand for education of the whole person (Watson, 2000a, p. 49). Holistic educators insist that schools are responsible to promote all dimensions of human development by attending to the physical, emotional, aesthetic, social, moral, and spiritual potential of students as well as to their intellectual abilities. They maintain that incorporating spirituality within public education will alleviate its chronic crises by addressing the needs students have for acceptance, community, and moral guidance that are too often neglected in schools.

Theme 3: The Transformed Consciousness We Need to Save the World

Many of spirituality's advocates believe that the problems experienced by students and teachers in public schools are symptoms of a broader social crisis that is itself a manifestation of human alienation. Such things as the warfare of nations, the deterioration of the environment, the persecution of minorities, the oppression of women, the gap between the rich and the poor, and many other sources of human suffering are all seen as evidence of our current condition of estrangement from "___," where the blank might be filled in with God, Gaia, our Inner/Higher 
Selves, our True Nature, or our Shared Humanity. (This is not, of course, an exhaustive list.) Here, incorporating spirituality within the curricula of public schools means setting students on a path to the transformed state of consciousness that our very survival as a species requires. Holistic Education again represents a case in point, as many of its programs include both personal and social transformation among their developmental goals: "Seeing the interconnectedness of all things, with nature as the foundation, is the basis of the new mind that the world needs for survival and ... the creation of this mind is the first responsibility of education." the salvation of schools and society are as varied as the interpretations of what it is that we are currently alienated from.

In sum: if there is one over-arching theme in the literature on spirituality in education, it is that of connection. Spirituality is typically presented as consisting of, or leading to, student experiences of connectedness with (a) their deepest selves, including all their hopes and fears; (b) other human and non-human souls, in all their similarities and differences; (c) the natural world and the cosmos beyond, in all its awe-inspiring complexity, beauty and mystery; and (d) the larger purposes, potentials, and powers that transcend ego's limited concerns. In virtue of its potential to foster these and other connections, spirituality in public schools is presented as the antidote to student indifference towards a fragmented curriculum, their rampant materialism and random vandalism, their callous indifference to social injustice, and their appalling apathy in the face of impending environmental catastrophe.

Students who feel deeply connected don't need danger to feel fully alive. They don't need guns to feel powerful. They don't want to hurt others or themselves. Out of connection grows compassion and passion-passion for people, for student's goals and dreams, for life itself. (Kessler, 1998, p. 52)

\section{Obstacles}

I am sympathetic to concerns that public schooling is neglecting-and perhaps obstructing-the spiritual development of its students and teachers. I believe that many of the aims and initiatives proposed by spirituality's advocates are worthy of further exploration. At the same time, I see three serious obstacles facing any attempt to introduce or reintroduce spirituality into public school curricula.

\section{Obstacle 1: Lack of Consensus on a New World View}

One obstacle to incorporating spirituality within public school curricula is a lack of consensus on what will replace the mechanistic world view. The mechanistic 
world view needs replacing because its materialism, determinism, and reductionism leaves no room for a spiritual dimension to reality. The mechanistic world view thus supports scientism, the assumption that what objectively exists can be known through scientific method, positivistically conceived; and that what cannot be so known lies within the realm of imagination, opinion, emotion, or (perhaps more charitably) "the arts." Once science conceived positivistically is accepted as the paradigm of knowledge, spirituality-along with morality and aesthetics-is seen to fall on the wrong side of the objective/subjective divide. ${ }^{5}$

Scientifically speaking, the mechanistic world view is long out of date. Unfortunately, however, this does not mean that it no longer influences what we do and do not accept as real. My concern here is that, so long as corresponding biases for "hard" over "soft" subjects continue to shape curriculum priorities, spirituality will be denied the status of a genuine form of knowledge and will have a very difficult time justifying its presence in schools. ${ }^{6}$ Conversely, I believe that legitimizing the inclusion of spirituality within public school curricula will require reference to a view of the world and of human potential that goes far beyond what is conceivable within a mechanistic cosmos.

The obstacle I see is not so much that there are no alternatives to mechanism and positivism as that there are too many. Some philosophical positions that reject the privileged epistemological status sometimes claimed for science-I am here thinking of anything-goes-radical-relativism-are no more hospitable to spirituality than positivism itself. Even among contemporary advocates of spirituality in education there are very different assumptions about the world and about what represents valid ways of knowing (Watson, 2000a, 2000b; Yob, 1995). The variety of metaphysical and epistemological viewpoints among spirituality's advocates is an obstacle to its inclusion in public schools because to speak of spiritual education or spiritual development presupposes that there are standards, principles, or processes with reference to which spiritual beliefs, attitudes, and practices are open to correction. To leave judgments about what is and is not genuine or wholesome or fruitful within spirituality to individual students is to abdicate the educator's responsibility, abandoning students to the perils of the spiritual path, which are legion.

Where are the criteria of genuine spirituality to be found? It seems to me that, although the potential for spiritual development might be the same among all of us-and even this is not universally agreed-our potential is only actualized through our initiation into the normative practices of some socially and historically conditioned tradition. (The same could be said, I suspect, about the development of 
the human capacity for speech, aesthetic appreciation, and much else.) Spirituality is not safe, then, in the sense of being as tradition-independent as its advocates sometimes suppose. The challenges to public education presented by cultural pluralism cannot be avoided simply by declaring spirituality independent of religious or institutional affiliations. ${ }^{7}$ The fate of Lawrence Kohlberg's claim to have discovered a culturally neutral schema of moral development should make us suspicious of any similar claims for a universal or tradition-free program of spiritual education. $^{8}$

In the absence of widely accepted standards, principles, or processes to assess spiritual beliefs, attitudes, and practices, advocates of spiritual education are forced into one of two alternatives, neither of which is compatible with responsible public schooling in a multicultural social context. ${ }^{9}$ The first alternative is to locate the understanding and practice of spirituality squarely within a particular tradition. An example here would be John Dominic Crossan (1998, p. 35; cf. Evans, 1993, pp. 1-4), who proposes to bracket the term spirituality in favour of sanctity: "The submission of human justice to divine justice, of human will to divine will, or, better, of human being to divine being." The second alternative is to define spirituality so broadly as to buy inclusion at the price of substantive normative content. An example here would be Parker Palmer (1998, p. 6; cf. Weaver \& Cotrell, 1992) who characterizes spirituality as "the ancient and abiding human quest for connectedness with something larger and more trustworthy than our egos." Defining spirituality in this very general way leaves it unclear how educators could object to students who find meaning and purpose in connectedness with a White Supremacist organization or a Satanic cult. Who decides, and how, what is and is not "more trustworthy"than our egos? Here, I think criticisms of Values Clarification's "laissez-faire" approach to moral education are instructive. ${ }^{10}$

In sum: The first major obstacle to incorporating spirituality with in public schooling is that those of us who reject mechanism and positivism have yet to agree on an alternative world view. ${ }^{11}$ Because we disagree on the nature of human potential and on the means of its realization, we lack consensus on the substantive criteria of genuine human development that responsible public education in spirituality would require.

Obstacle 2: Lack of Procedures for Reaching Agreement on the Goals of Public Schooling

Let us imagine that, on some happy day in the future, a combination of psychological research, philosophical inquiry, contemplative practice, religious 
study, critical social theory and cross-cultural dialogue produces a characterization of human spirituality that enjoys the unqualified approval of humanistic psychologists, philosophers of education, scholars of religion, spiritual seekers, deep ecologists, critical pedagogues, and religious authorities of all stripes. Let us further imagine that this account of spirituality is integrated within a coherent, comprehensive, and compelling account of human experience such that no "rational" person (however her qualifications are conceived) could, after due consideration, doubt its validity. Even such a remarkable (miraculous?) accomplishment would not in itself necessarily result in wide-spread changes to the curricula of public schools. The problem I see here is the lack of a clear set of procedures for (a) reaching agreement on what the broad aims of public schooling should be; (b) evaluating the extent to which-and for what reasons-public schools are or are not achieving their full range of objectives; and (c) holding those in public office accountable for supporting systems of public education adequately to achieve those objectives. A case in point would be the Atlantic Provinces Education Foundation (APEF) documents, which define the knowledge, skills, and attitudes that all graduates of Atlantic Canada's public school systems should possess. In these documents, many laudable educational goals are set forth under such headings as "Citizenship" "Problem-Solving" and "Personal Development". 12 However, the documents say very little about who was consulted to arrive at the list of desired outcomes, who will revisit that list in the light of feedback from the curriculum implementation process, and-perhaps most importantly-who will make the changes to existing systems of public education that will be required for those outcomes to be achieved. ${ }^{13}$

My general point here is that public school curriculum policy decisions are not (at least, in any obvious way) the outcome of reasoned public debate. ${ }^{14}$ This is in part because there is no general social agreement on what public schools should be for-a consensus that would provide a large part of the common ground required for productive argument. If I am correct on this point, then the lack of an empirically-supported, philosophically-sound, and cross-culturally accepted new world view is less an obstacle to bringing spirituality into public schools than the lack of accepted procedures to address competing educational priorities based upon conflicting political and economic agendas. Even if we could demonstrate that spiritual education is in the best interests of public school students, that would accomplish little if serving the needs of its students are not what public schools are really for.

I am not alone in this concern, as the following three quotes attest:

Modern schooling does not serve the spiritual unfolding of the child. It serves 
capitalism, nationalism, a reductionist world view. It serves a society that is completely committed to a meritocracy where there is fierce competition between individuals to reach the top of a social hierarchy" (Miller, 1999, pp. 190-191).

We currently drown students in low-level busy work, shove them together in forced associations which teach them to hate other people, not to love them. We subject them to the filthiest, most pornographic regimen of constant surveillance and ranking so they never experience the solitude and reflection to become a whole man or woman. (Gatto, 1999, p. 158)

Education everywhere is in crisis. This is true not just in the failed schools of our inner cities but also in our "successful" schools where we are spending huge sums to turn out graduates who lack a moral conscience to match the power of their skills to destroy, to make greedy profits, and to despoil the earth for future generations. It shows our preference for competition over mentorship and eldership. (Fox, 1998, p. 49)

A related concern is the centralized structure of most publicly-funded school systems. Even if curriculum decision-makers somehow became accountable to the outcome of public rational debate on the proper ends and means of schooling, we would still be left with the question of whether spirituality is something that ever could or should be fostered through state-run bureaucracies. Parker Palmer (1999, p. 30) suggests a negative answer: "I don't think that institutions are well suited to carry the sacred. Indeed, I think distortion is a great risk when the sacred gets vested in an institutional context or framework." Another concern is raised by Iris Yob. She notes that spiritual quests are typically all-consuming affairs and that "if a school program is to become involved in meaningful spiritual education, an occasional unit on spirituality in some social studies classes will be ineffectual at worst, merely supplemental at best, for pilgrimage is a way of life, the vehicle in which all other activities are carried along."

In sum: the second obstacle I see to incorporating spirituality within public schools is the political and economic priorities of our liberal institutions, and the corresponding centralized, bureaucratic structure of government systems of education. By obstructing, supplanting, or ignoring public debate on the proper priorities of public school curricula, these make it unlikely that spirituality will be taught or practised in schools in any meaningful way.

Obstacle 3: Who Will Teach the Teachers?

In response to concerns such as I have raised, advocates of spirituality in schools could propose that it be incorporated by teachers in their curricula in an ad hoc way using whatever opportunities exist in their particular educational contexts. I raise this possibility because, if the literature is correct, almost any aspect of 
schooling can become a vehicle for spiritual development under the direction of the right teacher. For example, with regard to the formal curriculum, Parker Palmer (1998, p. 8; cf. Miller, 1998, p. 47) claims that "the human quest for connectedness ... is at the heart of every subject we teach, where it waits to be brought forth." History teachers can draw connections to the dramas of the past; Science teachers can encourage connections with the wonders of the natural world; English teachers can open up connections to utopian futures through the realms of fiction; Phys Ed teachers can foster connections to the wisdom of the body; Art teachers can evoke connections to the sublime, and so forth. With regard to the more informal aspects of its curriculum, inspired teachers can use group projects, field trips, school plays, student councils, and community celebrations as occasions for spiritual work (Majmudar, 2000). The physical structure and environment of the school itself can also help create a spiritual milieu (Halford, 1998; Orr, 1999).

Advocates of spirituality in schools could also respond to my concerns by observing that the person to person interactions of students and teachers are the very heart of teaching, and here teachers cannot help but bring spirituality into their classrooms in the form of their own heart and soul. Palmer $(1998$, p. 10) insists that, "Whoever our students may be, whatever subject we teach, ultimately we teach who we are." Similarly, Mehlman (1991, p. 306) confesses that "I have come to believe that students experience as curriculum what the teacher is doing inwardly and spiritually." But there's the rub. In whatever scenario we envision, the success of initiatives to incorporate spirituality within schools will depend upon the abilities of the teachers involved, and particularly their degree of spiritual maturity. We can assume that those teachers already comfortable with bringing their personal understanding and practice of spirituality into their classrooms are currently doing what they can within existing public school systems. Conversely, neither publishing books and articles on spirituality in education nor providing neatly packaged programs will be enough to give other teachers the necessary qualifications to make spirituality flourish in schools. The problem facing advocates of spirituality in education is similar to that faced by proponents of Kohlberg's program of moral education: the need for teachers at the higher stages of human development to serve as role models. Who will teach them?

Some authors do provide some suggestions for how to encourage the spiritual development of pre-service and in-service teachers. However, they say very little about who will conduct these programs. If current post-secondary educational institutions are the product of the same alienated consciousness that has created the crises in elementary and secondary schools, and if current teacher 
educators are, like myself, the products and present occupants of those institutions-not to mention the former students of public schools-then the prospects for a spiritual revolution seem very dim indeed. ${ }^{15}$ Thus, the third obstacle I see to incorporating spirituality within public schooling is that it is not clear who would educate, or even be qualified to hire, the trustworthy spiritual mentors and guides that even ad hoc educational initiatives would require.

\section{So What To Do?}

I see no easy ways to remove, overcome or circumvent the obstacles I have mentioned. At the same time, I believe that simply identifying the obstacles serves to identify three ways in which its advocates could help prepare the ground for incorporating spirituality within public schools.

\section{Project 1: Work Toward a Shared Understanding of Spiritual Development}

Proposals to integrate spirituality into public schools would benefit from at least some consensus on the nature and conditions of genuine spiritual development and on the forms of education that foster it. Creating such a shared understanding of spiritual development would not require that we all come to belong either to the same historical tradition or to some new synthesis concocted in a spiritual melting pot. ${ }^{16}$ What it would require is reaching general agreement on the basics of a new view of the world and human knowing in which the claims of science and of spirituality could be reconciled. ${ }^{17}$ To this point, the conflict between science and religion has not been resolved so much as postponed by a policy of detente in which each is granted a separate sphere of influence. Co-existence based on mutual distrust is not enough because, so long as science and religion remain unreconciled, either spirituality will be denied a legitimate place in public schools or it will be admitted in an educationally inadequate form. ${ }^{18}$

Creating a shared understanding of spiritual development to inform educational initiatives in public schools would also require reaching agreement on a set of elemental moral principles or virtues that all programs would promote. This agreement would establish the basic moral framework within which cultural pluralism could flourish. If Alasdair MacIntyre (1988) is correct, it is neither necessary nor possible to meet the challenge of pluralism by attempting to discover or construct tradition-independent standards of moral and spiritual progress. To the extent consensus on such standards is possible, it will be achieved through on-going critical dialogue between competing points of view that can both discover and create common ground. According to my understanding of what is involved in 
critical dialogue, reaching agreement on a new world view and on a framework of basic moral principles or virtues are two aspects of the same multi-faceted process. ${ }^{19}$

I see at least two reasons to think that philosophers of education can contribute to productive critical dialogue among competing metaphysical, epistemological, moral, and spiritual perspectives. First, on at least one interpretation of philosophy, its central task is precisely "to show how to live well by the construction and rational justification of woridviews" (Kekes, 1980, p. xii; cf. ). Undertaking this task would involve integrating insights and evidence from many disciplines and modes of inquiry, and philosophers of education are already accustomed to bringing interdisciplinary perspectives to practical issues. Second, on the assumption that building consensus on the nature and conditions of spiritual development would be an on-going process, part of the project would be to help successive generations learn how to engage in productive critical dialogue. For example, students could be assisted in becoming both willing and able to question the materialistic, deterministic, and reductionistic world view that is still taken for granted in some science textbooks. Many philosophers of education already have much to say about the specifics of creating the conditions for productive critical dialogue, such as fostering open-mindedness, supporting critical and creative thinking, and building communities of inquiry within diverse student populations.

Project 2: Show That Holistic Education Works

As I have argued above, arriving at consensus on the nature and conditions of spiritual development would not guarantee that corresponding proposals for curriculum change would be implemented. Where public education is understood to reflect the economic and political priorities of the powers that be, it seems unrealistic to expect that even well-conceived proposals will suffice to bring about significant changes in schools-particularly if our social structures are symptomatic of an alienation deeply rooted in the human condition. The least one could say is that those who wish to resolve one or another perceived crisis in public education by incorporating spirituality within public schools must address the social and political dynamics that are keeping it out of the curriculum in the first place. In short, they must direct their attempts to effect change to the cultural chicken as well as to the educational egg. ${ }^{20}$

I profess no expertise in engineering large-scale social change. I do think one factor in successful institutional reforms, educational and otherwise, is the tension created when the gap between the goals and values professed by an organization and those embodied in its practices exceeds some undeterminable 
limit. To mobilize the energy for change created by that tension, remonstrations and protests should be accompanied by demonstrations that workable alternatives exist. All this to suggest that calls to incorporate spirituality within public schools can only increase their chances of success by pointing to successful precedents, prototypes, and pilot programs. Establishing and maintaining viable alternative schools is one way in which the efforts of those working for change outside the public educational system can complement the efforts of those working for change inside. $^{21}$

\section{Project 3: Nurture Your Own Spiritual "Connections"}

The third obstacle I have identified to incorporating spirituality within public schools is uncertainty over who is qualified to prepare or hire the experienced mentors and guides that responsible programs would require. Any adequate response to this issue would require that those concerned to promote the spiritual development of others, whether inside or outside of schools, attend to their own disciplines of spiritual study and practice. There is nothing, of course, more powerful than leading by example; or more suspect than failing to practice what is preached. I hasten to add that the necessity of taking time for one's own spiritual "work" need and should not serve to rationalize narcissistic self-preoccupation: Taking responsibility for oneself does not excuse failure to attend to one's responsibilities for others. Yet, we should not forget that the reverse also holds true. While many traditions would assert that our progress in spiritual development is arrested if we do not share its fruits with others, they would also caution that our efforts to benefit others will go astray if we have not ourselves experienced some relaxation of ego's fixations. ${ }^{22}$

A related point is that, if schools are to become hospitable environments for the spiritual development of teachers and students, then universities and colleges with teacher education programs must become hospitable environments for the spiritual development both of their faculty and of pre-service teachers. For if "higher" education cannot be persuaded to take holistic education seriously, then I see little hope that it will be championed by the government ministries responsible for public schools. What modern, secular universities could become if they began to take spirituality seriously is beyond my ability to imagine. However, I do think Eli Bay (1999) is on the right track in saying: "we need to get beyond judging ourselves and others solely by the standards of doing and open up to the importance of being." Conclusion

In this paper, I have presented three themes to summarize what proponents 
of spirituality in education believe their initiatives would offer students and teachers. I have identified three features of our cultural, social, political, and economic context that bode poorly for the success of such initiatives, and have proposed three projects in response. I must acknowledge, however, that even if those projects were undertaken with enthusiasm, their success would by no means be assured; and even their success would by no means guarantee spirituality a place in schools.

By speaking in general terms about their common themes, I have passed over many significant differences among the varied proposals to incorporate spirituality within public school curricula. This is in part because a nuanced treatment of individual programs is beyond the scope of a single article. It is also because, if my claim is correct, all such initiatives face the obstacles I have identified. Therefore, although generalization in this context is hazardous, I believe that those who wish to promote personal and social development through proper attention to spirituality in schools should take a long term view of their enterprise. Yet, it should also be said that bringing greater energy, purpose, and compassion to education are worthy of our best efforts inside and outside public schools. ${ }^{23}$

\section{Notes}

1. My bibliography indicates the authors to whom I refer. Some speak more of educating holistically or of inviting soul into classrooms than of incorporating spirituality, but the recommendations repeat essentially the same themes. For a critical interpretation from an American perspective of the cultural and social factors contributing to this revival of interest in spirituality, see Elias (1991).

2. On this point, Hayward (1999) is particularly emphatic, raising concerns about the impact of schooling on the ability of students and teachers to perceive sacredness in everyday experience.

3. Palmer (1998, p. 8). My own visits to schools suggest that this generalization applies more to secondary than elementary grades; and even then, of course, by no means universally.

4. Forbes (1996); compare Miller (1998, p. 47).

5. Positivistic views of knowledge are not as extinct as some would have us believe. See, for example, Mayer's (2000, pp. 38-39) remarks on what counts as educational research. For a discussion of the links between mechanism and positivism, see Vokey (in press, Chapter Three).

6. See Nixon (1999, pp. 628-629) for a historical perspective on the aversion of curriculum theorists to such things "mystical illumination." Labaree (1998) provides an analysis of how the distinction between hard and soft knowledge operates within programs of teacher education. 
7. On this point, see Watson (2000b, pp. 96-100), cf. Noddings (in Halford, 1998, p. 29).

8. For critical analyses of Kohlberg's Cognitive-Developmental approach to moral education, see Broughton (1985), Carter (1985, p. 19), Gilligan (1982), and Locke (1980, 1985).

9. See Siejk (1993) for a complementary argument that religious educators must directly address "the challenges and opportunities of teaching and learning within a multicultural society."

10. For critical analyses of Values Clarification, see Boyd \& Bogdan (1984, 1985), Carter (1984, pp. 49-53), and Lockwood (1975).

11. I do not wish to suggest that no progress has been made in this area. See Kidder \& Born (1998), Suhor (1998, p. 12), and Teasdale (1997).

12. The Atlantic Canada Framework for Essential Graduation Learnings in Schools (and a French version as well) can be viewed at http://www2.gov.pe.ca/educ/publications/apef.asp.

13. I should add that I doubt neither the intentions nor the abilities of those who produced the APEF documents. What I doubt was that their mandate was broad enough to ensure successful implementation of their educational objectives.

14. Pinar (1998, p. 14) makes a similar point: "Schools are no longer under the jurisdiction (it was probably always more professional than legal) of curriculum theorists."

15. For a related caution, see Gawitrha (1999).

16. In saying this, I am mindful of Watson's (2000a, p. 48) concern that "consensus models of spirituality do a disservice to the richness of lived spiritualities and are not based in any enduring reality."

17. The works of Huston Smith (e.g., 1989,1992) and Ken Wilbur (e.g.1985; 1997) come to mind in this regard.

18. On this point, see Nord (1999). See Singham (2000) for a discussion of how spirituality is undermined by the "two worlds model", in which jurisdiction over the physical realm is conceded by "elite religion" to "elite science;" cf. Larson \& Witham (1999).

19. For more on the nature and possibility of such critical dialogue, see Vokey (in press); cf. the Dalai Lama's message to the Millennium World Peace Summit (http://www.tibet.ca/ wtnarchive/2000/8/31_1.html).

20. In this connection, Nixon (1999) provides an interesting account of how the 1970s educational objective of "heightened consciousness" lost out to political activism in the competition for representation in school curricula. On the point that it is unrealistic to expect significant social change to result only from initiatives in schools, see Miller (1999, p. 193).

21. For example, the Shambhala Elementary School shows how it is possible for teachers to attend to their own spirituality and to that of their students without compromising more conventional educational goals. The School is based on the Enki curriculum "developed by Beth Sutton after 25 years of teaching in different contexts, including Waldorf" (Mark Szpakowski, http://halifax.shambhala.org/ses/faq.html). See also the description of the Kings View Academy and its GOLDLAKE ${ }^{\mathrm{sm}}$ Program at http://www.KingsViewAcademy. com/information.htm. I have no doubt there are many other schools and programs that could 
demonstrate the potential of an education that is infused with spirituality.

22. As Luke 17:2 reminds us, a blind or untrustworthy guide is worse than no guide at all.

23. My thanks go to the anonymous reviewers of this article for their helpful comments.

\section{References}

Barnes, Cynthia. (2000). "Holistic education, or, spirituality in education". Unpublished paper, University of Prince Edward Island, Charlottetown, PE.

Bay, Eli. (1999). "The relaxation response". Orbit, 30(2), 54-55.

Boyd, Dwight \& Bogdan, Deanne. (1984). "Something" clarified, nothing of "value": A rhetorical critique of values clarification'. Educational Theory, 34, 287-300.

Boyd, Dwight \& Bogdan, Deanne. (1985). "Rhetorical realities: A response to McAnich's interpretation of Values and Teaching". Educational Theory, 35, 327-330.

Broughton, John M. (1985). "The genesis of moral domination". In S. Modgil \& C. Modgil (Eds.), Lawrence Kohlberg: Concensus and controversy (pp. 363-385). London: Falmer Press.

Carter, Robert E. (1984). Dimensions of moral education. Toronto: University of Toronto Press.

Carter, Robert E. (1985). "Does Kohlberg avoid relativism?" In S. Modgil \& C. Modgil (Eds.), Lawrence Kohlberg: Consensus and controversy (pp. 9-20). London: Falmer Press.

COBWS. (1982). Winds from the wilderness. Toronto: Canadian Outward Bound Wilderness School.

Crossan, John Dominic. (1998). Spirituality or sanctity? Tikkun, 13(6), 34-35.

Elias, John L. (1991). "The return of spirituality: Contrasting interpretations". Religious Education, 86(3), 455-467.

Evans, Donald. (1993). Spirituality and human nature. Albany: State University of New York Press.

Fox, Matthew. (1998). "A spiritual renewal of education". Tikkun, 13(6), 49-50.

Foxworth, Marlin. (1998). "Putting spirituality in public schools". Tikkun, 13(6), 51-54.

Gatto, John T. (1999). "Education and the Western spiritual tradition". In Steven Glazer (Ed.), The heart of learning: Spirituality and education (pp. 115-171). New York: Jeremy P. Tarcher/Putnam.

Gawitrha. (1999). 'Toward a "new world" order: A native perspective'. In A. Walter Dorn (Ed.), World order for a new millennium: Political, cultural and spiritual approaches to building peace (pp. 213-218). New York: St. Martin's Press.

Gilligan, Carol. (1982). In a different voice. Cambridge, MA: Harvard University Press.

Gyatso, Tenzin. (1999). "Education and the human heart". In S. Glazer (Ed.), The heart of learning: Spirituality in education (pp. 85-95). New York: Jeremy P. Tarcher/Putnam.

Halford, Joan M. (1998). "Longing for the sacred in schools: A conversation with Nel Noddings". Educational Leadership, 56(4), 28-32.

Hayward, Jeremy. (1999). "Unlearning to see the sacred". In Steven Glazer (Ed.), The heart 
of learning: Spirituality and education (pp. 61-75). New York: Jeremy P. Tarcher/ Putnam.

Iannone, Ronald V. and Obenauf, Patricia A. (1999). "Toward spirituality in curriculum and teaching". Education, 119(4), 737-741.

Kekes, John. (1980). The nature of philosophy. Oxford: Basil Blackwell.

Kessler, Rachael. (1998). "Nourishing students in secular schools". Educational Leadership, 56(4), 49-52.

Kidder, Rushworth M. and Born, Patricia L. (1998). "Resolving ethical dilemmas in the classroom". Educational Leadership, 56(4), 38-41.

Labaree, David F. (1998). "Educational researchers: Living with a lesser form of knowledge". Educational Researcher, 27(8), 4-12.

Larson, Edward J. and Witham, Larry. (1999). "Scientists and religion in America". Scientific American, September, 88-93.

Lear, N. (1991). "Education for the human spirit". Education Digest, 56(7), 33-35.

Locke, Don. (1980). "The illusion of Stage Six". Journal of Moral Education, 9(2), 103-109.

Locke, Don. (1985). "A psychologist among the philosophers: Philosophical aspects of Kohlberg's theories". In S. Modgil \& C. Modgil (Eds.), Lawrence Kohlberg: Consensus and controversy (pp. 21-38). London: Falmer Press.

Lockwood, Alan L. (1975). "A critical view of Values Clarification". Teachers College Record, 76, 35-50.

MacIntyre, Alasdair. (1988). Whose Justice? Which Rationality? Notre Dame: University of Notre Dame Press.

Majmudar, Madhavi. (2000). "Moral and spiritual education through Sathya Sai Education in Human Values: A Cross-cultural approach". Paper presented at the International Conference of the Association for Moral Education, University of Glasgow, Glasgow, Scotland, July 7-11, 2000.

Mayer, Richard E. (2000). "What is the place of science in educational research?" Educational Researcher, $\mathrm{xx}(), 38-39$.

Mehlman, Clement. (1991). "Walden within". In Ron Miller (Ed.), New directions in education (pp. 306-318). Brandon, VT: Holistic Education Press.

Miller, John P. (1998). "Making connections through holistic learning". Educational Leadership, 56(4), 46-48.

Miller, Ron. (1999). "Holistic education for an emerging culture". In Steven Glazer (Ed.), The heart of learning: Spirituality and education (pp. 189-201). New York: Jeremy P. Tarcher/Putnam.

Nixon, Gregory M. (1999). "Whatever happened to 'heightened consciousness'?" Journal of Curriculum Studies, 31(6), 625-633.

Nord, Warren A. (1999). "Science, religion, and education". Phi Delta Kappan, 81(1), 28. 33.

Orr, David W. (1999). "Reassembling the pieces: Architecture as pedagogy". In Steven Glazer (Ed.), The heart of learning: Spirituality in education (pp. 139-149). New York: 
Jeremy P. Tarcher/Putnam.

Palmer, Parker J. (1999). "The grace of great things: Reclaiming the sacred in knowing, teaching, and learning". In Steven Glazer (Ed.), The heart of learning: Spirituality in education (pp. 15-32). New York: Jeremy P. Tarcher/Putnam.

Palmer, Parker J. (1998) "Evoking the spirit in public education". Educational Leadership, 56(4), 6-11.

Pinar, William F. (1998) “Gracious submission". Educational Researcher, 28(1), 14-15.

Postman, Neil. (1995). "What does the future hold for public education?" Paper prepared for the Canadian Teachers' Federation National Conference "Public Education: Meeting the Challenges," May, 1995.

Rolph, Jenny. (1991). "Can there be quality in teacher education without spirituality?" Assessment \& Evaluation in Higher Education, 16(1), 49-56.

Scheindlin, Laurence. (1999). "Preparing children for spirituality". Religious Education, 94 (2), 190-201.

Siejk, Kate. (1993). "An aspect of multicultural religious education: Re-visioning our epistemological foundations". Religious Education, 88(3), 434-450.

Singham, Mano. (2000). "The science and religion wars". Phi Delta Kappan, 81(6), 424432.

Smith, Huston. (1989). Beyond the post-modern mind (rev. ed.). Wheaton, IL: The Theosophical Publishing House.

Smith, Huston. (1990). "The central curricular issue of our age". In Mary E. Clark and Sandra A. Wawrytko (Eds.), Rethinking the curriculum: Toward an integrated, interdisciplinary college education (pp. 123-134). New York: Greenwood Press.

Smith, Huston. (1992). "Is there a perennial philosophy?" In J. Ogilvy (Ed.), Revisioning philosophy (pp. 247-262). Albany: State University of New York Press.

Suhor, Charles. (1999). "Spirituality-letting it grow in the classroom". Educational Leadership, 56(4), 12-16.

Teasdale, Wayne. (1997). "The interspiritual age: Practical mysticism for the third millennium". Journal of Ecumenical Studies, 34(1), 74-90.

Vokey, Daniel. (in press). Moral discourse in a pluralistic world. Notre Dame: University of Notre Dame Press.

Watson, Jacqueline. (2000a). "From transcendence to ethics: Shaping spirituality to schools". Journal of Beliefs \& Values, 21(1), 39-50.

Watson, Jacqueline. (2000b). "Whose model of spirituality should be used in the spiritual development of school children?" International Journal of Children's Spirituality, 5(1), 91-101.

Weaver II, R. L. and Cotrell, H. W. (1992). "A non-religious spirituality that causes students to clarify their values and to respond with passion". Education, 112(3), 426-436.

Wesley, Donald C. (1998). "Believing in our students". Educational Leadership, 56(4), 4245.Wilbur, Ken. (1985). No boundary: Eastern and western approaches to personal growth. Boston: Shambhala Publications. 
Wilbur, Ken. (1997). The eye of spirit: An integral vision for a world gone slightly mad. Boston: Shambhala Publications.

Yob, Iris M. (1995). "Spiritual education: A public school dialogue with religious interpretations". Religious Education, 90(1), 104-118.

Wilbur, Ken. (1985). No boundary: Eastern and western approaches to personal growth. Boston: Shambhala Publications.

Wilbur, Ken. (1997). The eye of spirit: An integral vision for a world gone slightly mad. Boston: Shambhala Publications.

Yob, Iris M. (1995). "Spiritual education: A public school dialogue with religious interpretations". Religious Education, 90(1), 104-118. 